\title{
The Effect of Religiosity and Ethical Orientation on Perceptions of Undergraduate Accounting Students on Creative Accounting
}

\author{
Intan Purnama Jaya ${ }^{1 \bowtie}$ and Sukirno ${ }^{2}$ \\ Economic Education Program, Postgraduate, Yogyakarta State University \\ Jl. Colombo No.1, Karang Malang, Caturtunggal, Depok, Sleman, Daerah Istimewa Yogyakarta 55281 \\ DOI: http://dx.doi.org/10.15294/jda.v12i1.17701
}

Submitted: May ${ }^{\text {th }}, 2019$ Revised: September $15^{\text {th }}, 2019$ Accepted: January $20^{\text {th }}, 2020$ Published: March $31^{\text {th }}, 2020$

\begin{abstract}
The purpose of this research is to determine the effect of religiosity and ethical orientation on the perception of creative accounting. The sampling technique used was purposive sampling technique. Students who participated as respondents were as many as 107 students from Universitas Negeri Yogyakarta and 249 students from Universitas Islam Indonesia who were then grouped based on criteria. The criteria used are already or are currently taking intermediate financial accounting 1 and intermediate financial accounting 2 courses, auditing courses, and business ethics courses. Based on the predetermined criteria, a sample of 202 students was obtained consisting of 98 Universitas Negeri Yogayakarta students and 104 Universitas Islam Indonesia students. The students involved in this study were given a questionnaire to fill in and the data obtained were analyzed using multiple regression methods. The results of this study indicate that there is an effect of religiosity on students' ethical perceptions in creative accounting. The students with high religiosity will have perceptions that are more ethical on creative accounting. The results of the analysis also show that ethical orientation has an effect on creative accounting. This means that the higher the ethical orientation of students, the more ethical their perceptions of creative accounting are.
\end{abstract}

Keywords: religiosity; ethical orientation; creative accounting

How to cite (APA 6th Style)

Jaya, I., \& Sukirno, S. (2020). The Effect of Religiosity and Ethical Orientation on Perceptions of Undergraduate Accounting Students on Creative Accounting. Jurnal Dinamika Akuntansi, 12(1), 68-76. doi:https://doi.org/10.15294/jda.v12i1.17701

\section{INTRODUCTION}

Accounting has varying definitions from the point of view of experts. In general, accounting is an activity of recording, interpreting data, and reporting of financial transactions of a company which can be used by interested parties in making economic decisions (Charles \& Walter, 2007; Renaldo, 2012; Roberts \& Scapens, 1985; Somantri, 2011). This means that accounting plays a very important role as a guide to financial statement information (Pamungkas, 2014).

Financial statements are prepared based on the standard rules for preparing financial reports as stipulated in the Decree of the Chairman of the Capital Market and Financial Institutions Supervisory Agency No: KEP-554 / BL / 2010. The rapid development of global and information technology in the market environment has led to changes in the conversion of accounting standards (PSAK) to International Financial Reporting Standards (IFRS) (Herawati, 2011; W., 2009). One of the basic principles of IFRS is principle-based approach that causes the author $(\triangle)$

E-mail: intanpurnama0706@gmail.com 
applicable rules to be more flexible, because it does not have specific standards for the industry (W., 2009). Flexible rules can provide opportunities for companies to do earnings management (Cahyonowati \& Ratmono, 2013). This earnings management act is usually known as creative accounting.

Creative accounting is an activity of changing financial information which includes accounting estimates, methods and practices that follow accounting principles and standards (Amat \& Gowthorpe, 2011). Creative accounting actions are not illegal if the recording of financial statements is carried out in accordance with applicable financial reporting standards (Diana \& Mădălina, 2008; Kamiński, 2014; Yadav, 2013). In contrast to the opinion stated by Odia \& Ogiedu (2013) that creative accounting is a fraudulent action by manipulating financial statement information for the benefit of the company. In line with the opinion of Remenaric, et al. (2018) who said that the activity of changing financial information in creative accounting provides a great opportunity for accountants to commit fraud.

Fraud committed by accountants in creative accounting aims to take advantage of assets, money, and not pay obligations (Tuanakotta, 2013). Another factor that becomes the reason for someone to commit fraudulent creative accounting practices is encouragement, opportunities, and rationalization (Tuanakotta, 2013). Based on the research conclusion of Sofyani \& Pramita (2014), it is known that creative accounting occurs because of superior authority and retaliation from superiors when superior orders are not carried out. However, not many people think that creative accounting is not an act that violates the rules. This causes irregularities in creative accounting action.

Deviation in creative accounting activities can be prevented by choosing accountants who have a good understanding of religion. Religion has an important role in a person's life to form beliefs, knowledge, attitudes, or behavior (Ateeq-ur-Rehman \& Shabbir, 2010). A person's religion has positive teachings that encourage a person to behave positively in various aspects of life, including economic activities (Hanafi \& Sobirin, 2002). The same thing is also stated by Saat et al (2016) that religion and belief have influence on ethical behavior in various life activities without exception in the economic and business fields.

High and low level of a person's belief or understanding in living up his / her religion is called religiosity. Religiosity is a person's actions based on religious teachings that motivate a person's attitude and actions according to prevailing religious norms and rules (Tikollah et al., 2006; Jalaluddin, 2011). Religiosity is also directly related to religion, lifestyle, beliefs, and God who rules the universe (Stark et al., 1982). Emerson \& Mckinney (2010) stated that religiosity is used as a determining factor for someone in ethics. Based on the conclusion of the research result conducted by Keller et al. (2007) also revealed that there are differences in someone's ethical standards based on education level, gender, work experience, and religiosity. This means that high religiosity of a worker can prevent the worker from committing fraud. In accordance with the research results of Stack \& Kposowa (2006) that is, the higher a person's religiosity, the lower the TFA (Tax Fraud Acceptability) level. Based on this description, the first hypothesis of this study is:

\section{H1: Religiosity has a positive effect on students' ethical perceptions on creative accounting.}

Apart from the level of religiosity, fraud in creative accounting can also be influenced by ethical orientation. This opinion is strengthened by the result of the research conducted by Himmah (2013) that ethical orientation (idealism and relativism), level of knowledge, and gender influence the ethical perceptions of accounting students regarding the ethical scandals of auditors and corporate managers. Ethical orientation is the embryo of a human thought process that can determine whether a person's actions are right or not (Primasari, 2014). According to Cohen et al. (1996), the first to determine the orientation of each individual is his needs. This need will affect a person's expectations and goals in making decisions. According to opinion (O'Higgins \& Kelleher, 2005) that ethical orientation is the mindset of individuals in dealing with ethical problems and the consequences of decisions taken. Research results from Comunale et al. (2006), 
it is found that the level of ethical orientation affects students' opinion on the actions of auditors, so that students with a high level of orientation will judge the actions of auditors more firmly. From the description above, the second hypothesis of this study is:

\section{H2: Ethical orientation has a positive effect on students' ethical perceptions on creative accounting.}

Based on the existing statements, it can be seen that religiosity and ethical orientation play an important role in suppressing creative accounting deviations. Thus, it is necessary to provide an early understanding of creative accounting ethics to accounting students in college before entering the business world. This is because education plays an important role in shaping the ethical behavior of accountants (Wati \& Sudibyo, 2016). In addition, accounting students will become successor accountants in the future who master and have more knowledge in economics. In accordance with the opinion of Aulia et al. (2015) that accounting students are future accountant candidates who understand the world of accounting even though for a while it is only at a theoretical level. Students' early understanding on creative accounting can be reviewed through students' ethical perceptions.

Perception is the process of entering and leaving information in the human mind which is influenced by the environment (Slameto, 1995). According to Mulyana (2007), perception is a process of interpreting stimuli from the surrounding environment that can influence a person's behavior. Different judgments about perceptions can be influenced by the level of religiosity and ethical orientation of a person. This is in accordance with the research results of Wati \& Sudibyo (2016) that there are differences in students' ethical perceptions who have high religiosity with students who have low religiosity. Other studies have also revealed that ethical orientation can influence students' perceptions about behaving in an ethical classroom (Allmon et al., 2000). Based on this, the third hypothesis of this study is as follows.

H3: Religiosity and ethical orientation have a positive effect on students' ethical perceptions on creative accounting.

\section{METHODS}

This research was included in the type of causality research using a quantitative approach. There were two kinds of research variables, namely dependent variable and independent variable. The dependent variable in this study was students' perceptions of creative accounting $(\mathrm{Y})$. The independent variables were religiosity (X1) and ethical orientation (X2).

The research was conducted at the Faculty of Economics, Universitas Negeri Yogyakarta and Universitas Islam Indonesia with a study program of accounting. The research was conducted at two different universities because of the differences in culture and environment of the two universities. Universitas Negeri Yogyakarta has a common culture and environment, while Universitas Islam Indonesia is based on religiousity. Thus, the data obtained from the two universities was more varied. The study was conducted in September 2018.

The population in this study were undergraduate students of accounting study program from Universitas Negeri Yogyakarta and Universitas Islam Indonesia. The total number of students used in this study were 805 students from batch 2016 and 2017, with details of 147 students of Universitas Negeri Yogyakarta and 658 students of Universitas Islam Indonesia (Table 1).

Table 1. Research Population

\begin{tabular}{|c|c|c|c|c|}
\hline \multirow{2}{*}{\multicolumn{2}{|c|}{ Name of Universities }} & \multicolumn{2}{|c|}{ Batch } & \multirow{2}{*}{ Total Students } \\
\hline & & 2016 & 2017 & \\
\hline \multicolumn{2}{|c|}{ Universitas Negeri Yogyakarta (UNY) } & 88 & 59 & 147 \\
\hline \multicolumn{2}{|c|}{ Universitas Islam Indonesia (UII) } & 237 & 421 & 658 \\
\hline \multicolumn{2}{|c|}{ Total } & & & 805 \\
\hline \multicolumn{5}{|c|}{ Source: Administration of UNY and UII (2018) } \\
\hline 70 & $\begin{array}{l}\text { Jurnal Dinamika Akuntansi } \\
\text { Vol. 12, No. 1, March 2020, pp. } 68-76\end{array}$ & & & \\
\hline
\end{tabular}


The sample technique in this study was purposive sampling technique using the Slovin formula, namely: $n=\frac{N}{1+N e^{2}}$ where $\mathrm{n}=$ total sample, $\mathrm{N}=$ total population, and $\mathrm{e}^{2}=$ error level $5 \%$. The sample used in this study were students who actively participated in accounting courses when the questionnaire was given. The number of students who participated as respondents was 107 students from Universitas Negeri Yogyakarta and 249 students from Universitas Islam Indonesia. Then, the samples were grouped based on the criteria. The criteria needed to be used as research samples were students who are taking or have taken auditing I and II courses, intermediate financial accounting I and II, and business ethics in batch 2016-2017. The results of grouping samples based on criteria can be seen in Table 2 .

Table 2. Research Sample

\begin{tabular}{lcc}
\hline \multicolumn{1}{c}{ Name of University } & Beyond Criteria & Included Criteria \\
\hline Universitas Negeri Yogyakarta & 9 & 98 \\
Universitas Islam Indonesia & 145 & 104 \\
\hline Total & 154 & 202 \\
\hline
\end{tabular}

Source: Primary Data Processed (2018)

Based on the data obtained from the table above, the sample that fits the research criteria was obtained as many as 202 students consisting of 98 Universitas Negeri Yogyakarta students and 104 Universitas Islam Indonesia students.

The data collection technique used a questionnaire which was distributed to the undergraduate accounting students of the UNY and UII accounting study program. The data that has been obtained were analyzed using multiple regression methods. The rating scale used for the assessment of each research variable was a Likert scale with 4 indicators. The indicators of this study were: (1) never (TP) with a score of $1,(2)$ rarely (JR) with a score of $2,(3)$ often (SR) with a score of 3 , and (4) always (SL) with a score of 4 (Table 3 ).

Table 3. Likert Scale for Measurement of Research Instruments of Religiosity and Ethical Orientation

\begin{tabular}{lcc}
\hline \multicolumn{1}{c}{ Indicators } & Positive Score & Negative Score \\
\hline Never (TP) & 1 & 4 \\
Rarely (JR) & 2 & 3 \\
Often (SR) & 3 & 2 \\
Always (SL) & 4 & 1 \\
\hline
\end{tabular}

Source: Suharsimi (2010)

Each research variable has different research indicators. The indicators used for the variable of accounting students' perception regarding creative accounting are a reduction in net income and an increase in net income (case A), as well as personal interests and the interests of the closest person (case B). Research indicators on this variable are adapted from Lan et al. (2015). The religiosity variable adapts the research indicators from Robbins et al. (1966) which consists of the ritualistic dimension, the ideological dimension, the intellectual dimension, the experiential dimension, and the consequential dimension. The ethical orientation variable uses indicators of idealism and relativism adapted from Greenfield et al. (2008). The research instrument grid can be seen in Table 4 . 
Table 4. Research Instrument Grid

\begin{tabular}{lll}
\hline No & Variables & Indicators \\
\hline 1. & Perceptions of Accounting Students & Case A \\
& Regarding Creative Accounting & 1. Reduction in Net Income \\
& & 2. Increase in Net Income \\
& Case B \\
& 1. Personal Interests \\
& 2. Interests of the Closest People \\
& 1. The ritualistic dimension \\
2. $\quad$ Religiosity & 2. The ideological dimension \\
& 3. The intellectual dimension \\
& 4. The experiential dimension \\
& & 5. The consequential dimension \\
& & 1. Idealism \\
3. Ethical Orientation & 2. Relativism
\end{tabular}

Source: (Lan et al., 2015; Greenfield et al., 2008; Robbins et al., 1966).

\section{RESULTS AND DISCUSSIONS}

Based on the results of the multiple linear regression test, it can be seen that there is an effect of religiosity on students' ethical perceptions. In addition, the results of the multiple linear regression tests also show the influence of ethical orientation on students' ethical perceptions.

Table 5. Results of Multiple Linear Regression Test

\begin{tabular}{lccc}
\hline Model & Beta & $\mathrm{t}$ & Sig \\
\hline (Constant) & 4.306 & 1.575 & 0.117 \\
Religiosity & 0.485 & 7.477 & 0.000 \\
Ethical Orientation & 0.253 & 3.383 & 0.001 \\
F Count $=39.314$ & & & \\
Significance $=0.000$ & & & \\
Adjusted $\mathrm{R}^{2}=0.276$ & & & \\
\hline
\end{tabular}

Source: Primary data processed (2018)

Based on the results of the multiple linear regression test, the regression equation is obtained as follows: $\mathrm{Y}=4.306+0.485$ religiosity +0.253 ethical orientation (Table 5 ). In the testing results of the first hypothesis, the t value of the religiosity variable was obtained to be 7.477 with a significance value of 0.000 . The significance value of religiosity $0.000<0.05$, describes that there is a positive influence of the religiosity variable on students' ethical perceptions. This means that the first hypothesis (H1) in this study is accepted.

The result of this study supports the previous research that the level of students' religiosity affect students' ethical perceptions (Wati \& Sudibyo, 2016). Students with high religiosity will have more ethical perceptions on accountants' ethical actions. In accordance with the opinion of Utomo \& Sofha (2018) that someone's ethical perception will be better if the level of religiosity is high, so that individuals will be aware of avoiding tax evasion. Bloodgood et al. (2008) also stated that someone who has high religiosity will not commit fraud and deception, while someone with low religiosity will have the opportunity to commit fraud. This is because a person's belief and religion affect their ethical behavior in various aspects of life, including the economic and business aspects (Saat et al., 2016). Every individual who has a high level of religiosity will tend to obey the teachings of his religion because they believe that if they commit an act that is prohibited by religion, the Creator will punish him. Thus, they will also obey the rules and norms that apply in the company, as long as the company regulations do not deviate from religious law. Phau \& 
Kea (2007) stated that there have been many studies that prove the theory of the existence of the relationship between religiosity and attitudes towards business ethics.

Based on the data seen in Table 5, it can also be seen that the regression value is 0.253 with the $t$ value for the ethical orientation variable is 3.383 and a significance value of less than 0.05 , namely 0.0001 . The result of this study indicates that the second hypothesis (H2) is accepted, which means that there is a positive influence of ethical orientation on students' ethical perceptions. The students who have a high ethical orientation will have more ethical perceptions on creative accounting.

The results of this test support the test results of previous researchers that ethical orientation has an influence on student perceptions, so that students who have a high level of orientation will tend to find it easy to identify ethical problems. (Leiwakabessy, 2010). In accordance with the opinion of Greenfield et al. (2008), one's ethical orientation mediates the impact of exploiting earnings management behavior. Besides that, Greenfield et al. (2008) also said that someone who has a high ethical orientation is less likely to commit fraud. The students who have a high ethical orientation will also be assertive in assessing deviant behavior by auditors (Comunale et al., 2006). Students who have an ethical orientation in themselves will behave in accordance with the existing rules and norms, so that each individual always acts ethically.

Table 6. Results of Determination Test $\left(\mathrm{R}^{2}\right)$

Model Summary

\begin{tabular}{lllll}
\hline Model & R & R Square & Adjusted R Square & Std. Error of the Estimate \\
\hline 1 & $0.532^{2}$ & 0.283 & 0.276 & 5.715 \\
\hline
\end{tabular}

Source: Primary Data Processed (2018)

The test result of Adjusted R Square in this study can be seen from the $\mathrm{R}^{2}$ value of this study, namely 0.276 . This means that the variables of religiosity and ethical orientation contribute to influence the ethical perceptions of students on creative accounting with a percentage obtained of $27.6 \%$, while the remaining of $72.4 \%$ is influenced by other variables from outside the study. The significance value of this test result is 0.000 . The significance value obtained is less than 0.05 , then the third research hypothesis $(\mathrm{H} 3)$ is accepted. Thus, religiosity and ethical orientation contribute simultaneously and significantly to students' ethical perceptions.

The result of this test is consistent with the test results of several previous researchers, namely the influence of students' religiosity on the level of ethical behavior (orientation) of accounting students, so that someone with a high level of religiosity will obey the rules or values set by religion (Hutahahean \& Hasnawati, 2015). In line with research of Allmon et al. (2000) conducted on business students from the United States and Australia with the result that ethical orientation, age and religious orientation have major influence on the perceptions of ethical class behavior (perceptions of business in the future). One of the conclusions from Rabin's research (2005) is that the higher the objectivity and integrity of auditors, the more their ability to detect creative accounting fraud. The research results of the three researchers support the result of the third hypothesis $(\mathrm{H} 3)$ of the researcher that religiosity and ethical orientation simultaneously influence students' ethical perceptions on creative accounting. This means that students with a high level of religiosity will tend to have a high ethical orientation, so that it will affect students' ethical perceptions on creative accounting practices.

The emergence of creative accounting is caused by many pressures that raised. Manager or company owner always has high standards for his business making creative accounting grows and develops in business and financial reporting. Sulistawan (2011) stated that creative accounting action is an unethical act and violates applicable norms. This action is also considered a criminal act because in this action accountants and auditors change financial data from what it should be to be what they want to be able to fulfil the quality of the company's financial statements. Basically, 
creative accounting is an action that may be taken because in this action the principles used are still accepted and in accordance with accounting standards, as long as the financial statements reported to shareholders do not cause a different perception. The same is stated by Aulia et al. (2015), creative accounting is not an easy matter to prove because some forms of creative accounting are not contradictory in accounting. The view of creative accounting is carried out by providing an early understanding in the academic world, namely to accounting students who will later enter the business world.

\section{CONCLUSIONS}

Based on the results of data analysis and discussion, it can be concluded that religiosity has a positive influence on students' ethical perceptions on creative accounting. This means that the level of students' religiosity can affect students' ethical perceptions on creative accounting practices. This means that the higher the students' religiosity, the more ethical their perceptions on creative accounting will be and the lower the students' religiosity, the lower their ethical perceptions on creative accounting.

The research result also shows the effect of ethical orientation on the ethical perceptions of accounting students in creative accounting. Thus, the level of students' ethical orientation can affect students' ethical perceptions. This means that the higher the students' ethical orientation, the more ethical their perceptions on creative accounting, so that they will be more firmly towards creative accounting practices.

Based on the research results, then it is put forward the theoretical implication that is the existence of empirical evidence regarding the influence of religiosity and ethical orientation on the ethical perceptions of accounting students in creative accounting at Universitas Negeri Yogyakarta and Universitas Islam Indonesia. In addition, the practical implications of the study results are: (1) the research results can be used as input for academia, especially in the fields of accounting and economics in higher education in discussing and educating students about religiosity and ethical orientation, because these can affect students' perceptions on creative accounting; and (2) the results of this research can be useful as a reference, input, or reference material for other researchers.

During the implementation of this research there are several limitations, namely: (1) the questionnaire is only distributed to accounting students of accounting study program from Universitas Negeri Yogyakarta and Universitas Islam Indonesia, so that the scope of research results is narrow and can not be generalized, (2) the sample of this study is limited to accounting students, (3) the variables of this study only examine the effect of religiosity and ethical orientation on students' perceptions; (4) the data from this study are only in the form of answers to the questionnaires from respondents.

Based on the research results and the research limitations, the suggestions that can be given are as follows: (1) it is expected that further researcher will expand the scope of research by using research samples from several universities in other areas, (2) it is expected further researcher to increase the coverage of questionnaire distribution, it is not only limited to accounting students, but it can also be given to audit accountants and educators so that the data obtained is clearer and more accurate, (3) further researchers can add other variables to be studied, because ethical perception is not only influenced by religiosity and ethical orientation, and (3). 4) It is expected that further researcher will collect data not only based on the results of the questionnaire, but can be added with the results of the interview so that the data obtained is clearer and more complete.

\section{REFERENCES}

Allmon, D. E., Page, D., \& Rpberts, R. (2000). Determinants of Perceptions of Cheating: Ethical Orientation, Personality and Demographics. In Journal of Business Ethics, 23(4), 411-422.

Amat, O., \& Gowthorpe, C. (2011). Creative Accounting: Nature, Incidence and Ethical Issues. SSRN Electronic Journal, 1-19, https://doi.org/10.2139/ssrn.563364.

$74 \quad$ Jurnal Dinamika Akuntansi Vol. 12, No. 1, March 2020, pp. 68-76 
Ateeq-ur-Rehman, \& Shabbir, M. S. (2010). The Relationship Between Religiosity and New Product Adoption. Journal of Islamic Marketing, 1(1), 63-69.

Aulia, R., Arif, M. L. S., \& Herawati, N. (2015). Persepsi Mahasiswa Akuntansi tentang Praktik Creative Accounting. Jurnal Akuntansi Multiparadigma, 5(1), https://doi.org/10.18202/jamal.2014.04.5009.

Bloodgood, J. M., Turnley, W. H., \& Mudrack, P. (2008). The Influence of Ethics Instruction, Religiosity, and Intelligence on Cheating Behavior. Journal of Business Ethics, 82(3), 557-571.

Cahyonowati, N., \& Ratmono, D. (2013). Adopsi IFRS dan Relevansi Nilai Informasi Akuntansi. Jurnal Akuntansi dan Keuangan, 14(2), 105-115.

Charles, T., H. \& Walter, T., H. (2007). Akuntansi Jilid Satu. Edisi Tujuh. Jakarta: Erlangga.

Cohen, J., R., L., W. \& Sharp, D., J. (1996). Measuring The Ethical A Wareness and Ethical Orientation of Canadian Auditor, Research in Accounting, 7, 37-64.

Comunale, C. L., Sexton, T. R., \& Gara, S. C. (2006). Professional Ethical Crises. Managerial Auditing Journal, 21(6), 636-656.

Diana, B., \& Mădălina, P. C. (2008). Is Creative Accounting A Form of Manipulation? Annals of The University of Oradea, Economic Science Series, 17(3), 935-940.

Emerson, T. L. N., \& Mckinney, J. a. (2010). Importance of Religious Beliefs to Ethical Attitudes in Business. Journal of Religion and Business Ethics, 1(2), 1-17.

Greenfield, A. C., Norman, C. S., \& Wier, B. (2008). The Effect of Ethical Orientation and Professional Commitment on Earnings Management Behavior. Journal of Business Ethics, 83(3), 419-434.

Hanafi, S. M., \& Sobirin, A. (2002). Relevansi Ajaran Agama dalam Aktivitas Ekonomi (Studi Komparatif antara Ajaran Islam dan Kapitalisme). Iqtisad Journal of Islamic Economics, 3(1), 16-34.

Herawati, N. T. (2011). Konvergensi International Financial Reporting Standards (IFRS) dan Implikasinya Terhadap Pembelajaran Akuntansi Pengantar di Perguruan Tinggi. Jurnal Ilmiah Akuntansi dan Humanika, 1(1).

Himmah, E. F. (2013). Persepsi Etis Mahasiswa Akuntansi Mengenai Skandal Etis Auditor dan Corporate Manager. Jurnal Akuntansi Multiparadigma, 4(1), 26-39.

Jalaluddin. (2011). Psikologi Agama. Jakarta: PT. Rajagrafindo Persada.

Hutahahean, M. U. B., \& Hasnawati, H. (2015). Pengaruh Gender, Religiusitas dan Prestasi Belajar Terhadap Perilaku Etis Akuntan Masa Depan (Studi Pada Mahasiswa Akuntansi Perguruan Tinggi Swasta di Wilayah DKI Jakarta). Jurnal Akuntansi Trisakti, 2(1), 49-66.

Kamiński, R. (2014). Creative Accounting Does Not Need to Equal Falsification of Accounts. Economics World, 2(4), 272-280.

Keller, A. C., Smith, K. T., \& Smith, L. M. (2007). Do Gender, Educational Level, Religiosity, and Work Experience Affect The Ethical Decision-Making of U.S. Accountants? Critical Perspectives on Accounting, 18(3), 299-314.

Lan, G., Gowing, M., \& Al-Hayale, T. (2015). The Role of Intent on Accounting Students' Ethical Attitudes Towards Earnings Management. Journal of Academic Ethics, 13, 345-362.

Leiwakabessy, A. (2010). Pengaruh Orientasi Etis dan Budaya Jawa Terhadap Perilaku Etis Auditor. Jurnal Manajemen Akuntansi \& Sistem Informasi, Program Magister Akuntansi Universitas Diponegoro, 10(1), 1-15.

Mulyana, D. (2009). Ilmu Komunikasi. Suatu Pengantar. Bandung: PT. Remaja Rosdakarya.

Tikollah, M., R., Iwan T., \& H. Unti, L. (2006). Pengaruh Kecerdasan Intelektual, Kecerdasan Emosional dan Kecerdasan Spiritual Terhadap Sikap Etis Mahasiswa Akuntansi (Studi Pada Perguruan Tinggi Negeri di Kota Makassar Provinsi Sulawesi Selatan). Simposium Nasional Akuntansi 9 Padang, 1-25.

O'Higgins, E., \& Kelleher, B. (2005). Comparative Perspectives on The Ethical Orientations of Human Resources, Marketing and Finance Functional Managers. In Journal of Business Ethics, 56, 275-288.

Odia, J. O., \& Ogiedu, K. O. (2013). Corporate Governance, Regulatory Agency and Creative Accounting Practices in Nigeria. Mediterranean Journal of Social Sciences, 4(3), 55-66.

Pamungkas, I. D. (2014). Pengaruh Religiusitas dan Rasionalisasi dalam Mencegah dan Mendeteksi Kecenderungan Kecurangan Akuntansi. Jurnal Ekonomi Dan Bisnis, 15(2), 48-59.

Phau, I., \& Kea, G. (2007). Attitudes of University Students Toward Business Ethics: A Cross-National Investigation of Australia, Singapore and Hong Kong. Journal of Business Ethics, 72(1), 61-75.

Primasari, N. H. (2014). Pengaruh Orientasi Etika, Gender, Pengetahuan tentang Profesi Akuntan dan Pengetahuan tentang Skandal Keuangan terhadap Penilaian atas Tindakan Auditor (Studi Empiris pada Mahasiswa Akuntansi Universitas Budi Luhur). Jurnal Akuntansi Dan Keuangan, 3(2), 151167. 
Rabin, CE. (2005). Determinants of Auditor's Attitudes Towards Creative Accounting. Meditari Accountancy Research, 12(2), 67-88.

Remenaric, B; Kenvelja, I; Mijoc, I. (2018). Creative Accounting - Motives, Techniques and Possibilities of Prevention. Ekonomski Vjesnik / Econviews : Review of Contemporary Business, Entrepreneurship and Economic Issues, 31(1), 193-199.

Renaldo, M. (2012). Penerapan Akuntansi Pada Usaha Kecil Menengah. Jurnal Akuntansi, 1(2), 57-62.

Robbins, R., Glock, C. Y., \& Stark, R. (1966). Religion and Society in Tension. American Journal of Sociology, Book Review, 74(5), 545.

Roberts, J., \& Scapens, R. (1985). Accounting Systems and Systems of Accountability - Understanding Accounting Practices In Their Organisational Contexts. Accounting, Organizations and Society, 10(4), 443-456.

Saat, M., Porter, S., \& Woodbine, G. (2016). Does Religiosity Influence Ethical Sensitivity? An Investigation on Malaysian Future Accountants. Malaysian Accounting Review, 8, 17-41.

Slameto. (1995). Belajar dan Faktor-Faktor yang Mempengaruhinya. Jakarta: Bhineka Cipta.

Sofyani, H. \& Pramita, Y., D. (2014). Otoritas Atasan, Retaliasi, dan Locus of Control sebagai Faktor-Faktor yang Mempengaruhi Perilaku Manipulasi Laporan Realisasi Anggaran, 3(2), 427-436.

Somantri, H. (2011). Memahami Akuntansi. Bandung: Armico.

Stack, S., \& Kposowa, A. (2006). The Effect of Religiosity on Tax Fraud Acceptability: A Cross-National Analysis. Journal For The Scientific Study of Religion, 45(3), 325-351.

Stark, R., Kent, L., \& Doyle, D. P. (1982). Religion and Delinquency: The Ecology of A “Lost” Relationship. Journal of Research In Crime and Delinquency, 77, 4-24.

Sulistawan, et al. (2011). Creative Accounting: Mengungkap Manajemen Laba dan Skandal Akuntansi. Jakarta: Salemba Empat.

Tuanakotta, T., M. (2013). Audit Berbasis ISA (International Standards on Auditing). Jakarta: Salemba Empat.

Utomo, D., \& Sofha, D. (2018). Keterkaitan Religiusitas, Gender, Lom dan Persepsi Etika Penggelapan Pajak. Jurnal Ilmu Manajemen dan Akuntansi Terapan (JIMAT), 9(2), 43-60.

W., H. S. (2009). Konvergensi Standar Laporan Keuangan ke Standar Pelaporan Keuangan Internasional, Apa dan Bagaimana. The Winners, 10(1), 10-21.

Wati, M., \& Sudibyo, B. (2016). Pengaruh Pendidikan Etika Bisnis dan Religiusitas Terhadap Persepsi Etis Mahasiswa Akuntansi. Jurnal Economia, 12(2), 183.

Yadav, B. (2013). Creative Accounting: A Literature Review. The SIJ Transactions on Advances in Space Research \& Earth Exploration, 1(5), 181-193. 